\title{
SUPERVENING IMPOSSIBILITY OF PERFORMING CONDITIONS PRECEDENT*
}

The life history of a contract may be outlined as follows: First, preliminary inquiries and negotiations wholly inoperative as to legal consequences; secondly, a communication by one party called an offer, an act operating to create in the offeree a legal power, and usually leaving in the offerer a power of revocation; thirdly, action by the offeree called acceptance, making what we are accustomed to call a contract (the rules as to mutual assent, consideration, form, and legality being complied with); fourthly, performance or breach; and lastly, discharge. Observe that this is a mere outline of history, covering all the contractual ages from embryo to tombstone. To fill in all the details of this outline would require from four to seven volumes.

The subject of this article falls within the fourth head-performance or breach. Acceptance makes a contract; it creates a bundle of legal relations that need analysis and description. But among these relations we may not find a duty of instant performance. Some important subsequent fact, an act of a person or some other event, may be a condition precedent to such a duty. Perhaps the most difficult and the most interesting question in the law of contracts is: When is a condition? The answer to this question in any particular case depends upon the expressions used by the parties, upon the actual will and intention of the parties, upon what they would have willed and intended if their imagination had anticipated subsequent events, and upon what the interests of society require. Our question is much more limited than this, although its answer depends upon the same considerations. Like true Hibernians, we are to discuss the question: When is a condition not a condition? Assuming that certain facts would operate as conditions of an obligor's duty as long as they are possible of occurrence, how is their operation affected by supervening impossibility?

Impossibility may be considered (1) with respect to the time it exists, either existing at the time the contract is made or arising subsequently; (2) with respect to its being known or not known; (3) with respect to the operative effect of the act or event that is impossible, either as an act promised or as a condition of another's promise; (4) with respect to its character and extent,-for as the term is loosely used there

* The purpose of this article is to indicate some of the legal consequences as to the obligor of nonperformance by the obligee of a condition of the obligation because of impossibility which arises after the formation of the contract. In successive numbers of the Columbia LAw Review, these legal consequences in particular fields of the law. will be treated by other authors.-Editors' note. 
are degrees of impossibility, including illegality, unexpected difficulty, danger to life or property, economic unprofitableness, and mere personal inability; (5) with respect to its cause, including acts of God, the state, third persons, the obligor, the obligee.

Time and space do not here permit the discussion of all of these aspects of impossibility; and indeed the subject does not include them all. For example, it does not deal with impossibility existing at the date of the agreement. A discussion as to the degree of inpossibility and as to its cause might be quite within the subject, but will not now be attempted. Reasons will be given for excluding only one or two important classes of cases.

When one is under a legal duty, whether created by contract or otherwise, and the performance required of him becomes illegal or 'objectively impossible, the duty is extinguished. Society no longer commands performance. Lex non cogit ad impossibilia. Nor is any new and secondary duty created to pay damages.

Thus if one has contracted to paint a house, and the house burns down before performance, the painter is under no further duty. If one has promised to render personal service for a definite time, and cannot do so because of death or illness, his duty is discharged. The rule is based upon settled convictions of the community; although it is ofter1 said to rest upon the intention of the parties. In fact, it frequently makes no difference whether such an intention exists or not. ${ }^{1}$

In the subject now under discussion, however, the above question is not involved. We are dealing not with the nonperformance of acts by an obligor as required of him by his legal duty, but with nonperformance of a condition by an obligee.

A special suggestion may be made with respect to penal bonds. A penal bond is often so worded as to make it appear that the obligor's sole duty is to pay the penalty, on condition that if he does a certain other act his duty is to be void. Thus in Blandford v. Andrews ${ }^{2}$ the defendant was held and firmly bound in the penal sum of eighty pounds; but the condition of the obligation was that if the defendant should induce Bridget Palmer to marry the plaintiff the bond was to be void. This looks like a duty to pay eighty pounds with a condition subsequent. The fact was, however, that the eighty pounds were to be paid as a penalty for failure to induce Bridget to marry the plaintiff. The defendant's primary duty was to prevail upon Bridget, not merely to pay a sum of money. This was early perceived by courts of equity. L,ooking behind the mere form of words, they saw what the real duty was, and they refused to enforce the penalty if it was out of proportion to the loss caused by the defendant's breach. This explains why in many cases

1 Of course one can bind himself as an insurer; but in such case the duty is to prevent loss or to pay for it. The performance promised is not impossible.

2 (1599) Cro. Eliz. 694. 
it is said that there has been a "breach of the condition" by the defendant (clearly a misuse of the word condition). The defendant has in fact committed a breach, but it is a breach of duty, not a breach of a condition. In a case like this, if performance of the misnamed condition by the defendant becomes truly impossible, as by the death of any one of the parties, the defendant's duty would be wholly terminated and the penalty uncollectible. Observe that this is not within our subject; it is not a nonperformance of a condition by an obligee, but is a nonperformance of duty by an obligor. As long as the common law courts took the words at their face value and enforced payment as if that was what the primary duty required, the case of the penal bond would properly be included in our present discussion.

In like manner we must exclude cases of prospective impossibility of performance by an obligee where the actual performance itself is not a condition. In a certain case ${ }^{3}$ the defendant promised to deliver railroad ties, and in return the plaintiff promised to pay cash on presentation of the bill of lading, inspection certificate, and invoice at the Bank of California. Shipment and tender of the bill of lading were to precede payment. Obviously the performance promised by the plaintiff-the payment of the price-was not a condition precedent to the defendant's duty to deliver the ties. Yet in a suit by the buyer for damages for failure to ship and deliver, the defendant won on the ground that the plaintiff had made no preparations to pay the price and there was evi. dence for the jury that he was unable to pay as agreed. Here is a case of inability to perform on the part of an obligee, and its legal consequence is that the obligor's duty to ship never arose; but it is not inability to perform a condition, for payment was not a condition. Prospective ability to pay is a constructive condition precedent to the defendant's duty to deliver; but such ability has not become impossible, it merely does not exist.

In discussing the cases that fall properly within our subject, we must first consider the meaning of the word "condition." No doubt, it is our ancient and inalienable privilege to use words in such sense or nonsense as we please. I shall proceed to act in accordance with this privilege. In my discussion, "condition" does not mean a group of words or the thought expressed by them. It is not a "proviso" in a contract or a "term" thereof. Instead, it is a fact the existence or future occurrence of which is uncertain, and in the absence of which certain contemplated legal relations will not exist. It may be an act of the obligee or of another person, or it may be an event other than an act. To be a con-

${ }^{3}$ McCormick v. Tappendorf (1909) 51 Wash. 312, 99 Pac. 2. As to the effect of a buyer's insolvency, see Pardee v. Kanady (1885) 100 N. Y. 121, 2 N. E. 885; Ex parte Chalmers (1873) I. R. 8 Ch. 289. 
dition at all, however, it must be an operative or causal fact that will create new legal relations, or extinguish old ones, or both. ${ }^{4}$

The particular legal relation to be created or extinguished by the occurrence of this operative fact may be any relation recognized as such in any analytical system. The particular one contemplated, however, is usually a right and its correlative duty. The creation or extinguishment of some right and duty is the legal consequence that is here under consideration.

It is not every operative or causal fact that is customarily described as a condition. Our subject is limited to "a condition of the obligation." This appears not to include those facts that are necessary to the formation of a contract, such as offer, acceptance, consideration, delivery, although they create new legal relations. It includes only facts subsequent to acceptance of the offer and antecedent to any complete discharge. Illustrations of a condition as above defined are as follows:

(1) Clobery promised Constable to pay freight if a ship returned to the Downs. ${ }^{5}$ What we call a contract was formed, but there was as yet no enforceable duty of instant payment. Before such a duty could exist it appears to be necessary for the ship to return to the Downs. The return of the ship was, by express words, a condition precedent to Clobery's duty to pay and to Constable's right to payment. If the condition became impossible by the sinking of the ship, must Clobery pay freight?

(2) A painter promises to paint B's house for five hundred dollars promised in return by $B$. Here the painting is a condition precedent to B's duty to pay and to A's right to payment. It is not made so by express words; but it is said to be an implied condition. If the painting becomes impossible by the burning of the house, no court will require the owner to pay five hundred dollars. Most American courts will require him to pay the reasonable value of such improvement as the painter had made upon his house prior to the fire. ${ }^{6}$ The condition in this case is a long series of acts by the painter or his servants, and they constitute the expected equivalent of the owner's payment.

(3) In the well-known case of Poussard v. Spiers, ${ }^{7}$ Madame Poussard promised to act as a leading operatic singer, and Spiers promised to employ and pay her for a definite period. Illness prevented her from attending rehearsals and from taking part in the important opening performance. Spiers had no claim for damages for her breach of promise.

${ }^{4} \mathrm{We}$ are examining the legal consequences of "nonperformance by the obligee." Taken literally, this would not include acts of third persons or events that are not acts of any person. It seems unnecessary, however, to adhere to the literal interpretation, as the principles involved are identical.

s Constable v. Clobery (1626) Latch 49, Palmer 397.

- Butterfield v. Byron (1891) 153 Mass. 517,27 N. E. 667 ; Carroll v. Bowersock (1917) 100 Kan. 270, 164 Pac. 143 ; contra, Appleby v. Myers (1867) L. R. 2 C. P. 651 .

:(1876) 1 Q. B. D. 410. 
Impossibility terminated her duty to sing. But on the other hand, Spiers was privileged not to employ her at all. Her appearance and ability to perform were by construction of law conditions of the duty of Spiers. Impossibility of performing these conditions did not make his duty absolute and unconditional. Instead he was under no duty at all. Here, too, the acts not performed by Madame Poussard formed the expected equivalent for the payment by Spiers. ${ }^{8}$

(4) Suppose the case of a life insurance contract where the duty of the insurer to pay is expressly conditional upon the payment of annual premiums on certain days. In a number of cases the payment of these premiums on time became illegal and practically impossible by the breaking out of the Civil War in 1861. The non-payment of the premium was not a breach of duty by the insured, for he had made no promise to pay premiums; but it was the nonperformance of an express condition precedent to the right of the beneficiary. The United States Supreme Court held by a majority that the insurer was under no duty to pay anything on the policy, but that he must pay the equitable value to the estate of the insured.9 ${ }^{9}$ The state courts have differed in their decisions. ${ }^{10}$

(5) Accident insurance policies often require that notice shall be given within a specified number of days after the accident as a condition precedent to the duty of the insurer. The death, insanity, or illness of the insured, caused, it may be, by the very accident insured against, may make it impossible for the insured to cause such notice to be given. Of course the notice may be given by another person, but this appears to be overlooked by the courts. Most courts hold that the requirement of notice is nullified and the insurer must pay.1 New York has held contra, ${ }^{12}$ and Wisconsin holds ${ }^{13}$ that the insurer must pay, solely on the ground that such has become the established rule, and insurance contracts must be regarded as having been made in contemplation thereof.

(6) It is sometimes provided in contracts of insurance and of suretyship that in case any dispute arises, the duty of the obligor shall cease unless the obligee shall bring suit within twelve months from the date of loss. If the obligor has in fact no other defense than this, he comes under an instant duty to pay, but the duty will be extinguished by a failure to bring suit within the specified period. Such a failure to sue is a condition of the obligation, but it is a condition subsequent to the

8 In Horlock v. Beal [1916] 1 A. C. 486 , the court held that a sailor could not maintain suit for his wages when he was prevented from performing the agreed service by being captured and imprisoned by the Germans during the war.

${ }^{9}$ New York Life Ins. Co. v. Stathain (1876) 93 U. S. 24.

10 Mutual Benefit Life Ins. Co. v. Hillyard (1874) 37 N. J. L. 444 (the dissenting opinion is far the better); Abell v. Penn Mutual Life Ins. Co. (1881) 18 W. Va. 400.

${ }_{11}$ Reed v. Loyal Prot. Ass'n (1908) 154 Mich. 161, 117 N. W. 600.

12 Whiteside v. North Amer. Acc. Ins. Co. (1911) 200 N. Y. 320,93 N. E. 948.

${ }^{13}$ Comstock v. Fraternal Acc. Ass'n (1903) 116 Wis. 382, 93 N. W. 22. 
duty of performance by the obligor, not precedent to it. Suppose the failure to sue is caused by the outbreak of war making such a suit impossible without crossing the line of hostilities and therefore illegal, ${ }^{14}$ or by an injunction or other governmental action, ${ }^{15}$ or by death of the obligee without any personal representative. ${ }^{16}$ It is usually held that action lies after the expiration of the period. Observe that the fact operating as a condition subsequent-the failure to sue-is not rendered impossible, but instead is made inevitable by unexpected circumstances. If, however, we consider the right to judgment and not the right to payment, it may be said that the bringing of the suit is a condition precedent to the right, a condition that has become impossible. This would bring these cases within the subject of our discussion.

(7) In building contracts a certificate of the architect is frequently in express terms made a condition precedent to the owner's duty to pay one or more instalments. ${ }^{17}$ Inasmuch as courts disregard these conditions when the certificate is refused by the architect for some dishonest reason, we need not be surprised to find that the condition is likewise disregarded if the certificate becomes impossible by death or insanity of the architect, or otherwise.

The Massachusetts court distinguished this case from that of a contract of insurance where a certification of some sort is often made a condition precedent. ${ }^{18}$ It said,

"A provision like the one before us in this kind of contract, where the substance of the consideration on one side is valuable property in the form of labor or materials, is materially different from the provision in the policies of insurance. . . . ${ }^{19}$ In these contracts of insurance a small sum is paid on one side to obtain indemnity from the possible consequences of a risk. . . . The compensation is to be paid only for genuine losses. . . . Satisfactory proof of their character . . . is of the very essence of the contract. On that depends the obligation of the insurer to pay a very large sum for which only a small consideration is given."

With due respect to the court, it is believed that "satisfactory proof" of performance by a builder is as necessary for the protection of the owner as is such proof that a claimed loss is genuine in an insurance case. In either case, other kinds of proof may in the minds of court and jury be equally good as the required certificate; while in neither case may other kinds of proof be equally satisfactory to the obligor.

I4 Semmes v. Hartford Ins. Co. (U. S. 1871) 13 Wall. 158; Earnshaw v. Sun Mutual Aid Soc. (1888) 68 Md. 465, 12 Atl. 884; Phoenix Ins. Co. v. Underwood ('Tenn. 1873) 12 Heisk. 424.

15 Jackson v. Fidelity \& Casualty Co. (C. C. A. 1896) 75 Fed. 359. Cf. Jinmings v. Amend (1917) 101 Kan. 130, 165 Pac. 845.

${ }_{16}$ Eliot Nat. Bk. v. Beal (1886) 141 Mass. 566, 6 N. E. 742.

17 Observe that here the condition is not an act to be "performed" by the obligee.

${ }_{18}$ Hebert v. Dewey (1906) 191 Mass. 403,77 N. E. 822.

19 See Worsley v. Wood (1796) 6 T. L. R. 710. 
A somewhat different distinction will now be attempted. In determining whether a fact shall operate as a condition of the obligor's duty, the courts do not and should not rely solely upon the words used by the parties. In general, the so-called express condition suffers the same fate as does the condition that is described as implied or constructive. 'The courts do not make agreements for the parties, but they do not ask the parties what legal relations they intended to create. The prevailing concept of justice appears to require only that the obligor should not be forced to perform in case he has not. received the stbstantial equivalent of his performance as agreed upon. If, therefore, the fact that is described as a condition forms a substantial part of this agreed equivalent, the obligor is not under the agreed promissory duty in case of its nonperformance; and this is the case even though such nonperformance is due to supervening impossibility without fault in the obligee. Thus the painter does not get the price of his work if he does not paint, nor the singer if she does not sing. In case of part performance, justice requires payment to the extent of value received, without regard to the contract. ${ }^{20}$

If, on the other hand, the fact that is alleged to operate as a condition forms no part of the agreed equivalent of the obligor's performance, to compel the obligor to perform in its absence does not compel him to give something for nothing. In the building contract cases the owner was not paying for a certificate; he was paying for a building. The large payment by an insurance company is not given in return for the notice of accident within ten days or in return for the bringing of a suit within twelve months from date of loss. Uncontemplated impossibility can be held to nullify these conditions without robbing the insurer of any part of his quid pro quo, and the insurer is very generally required to pay.

The same cannot be said, however, where the condition that becomes impossible is the payment of an insurance premium. Such premium is the only equivalent the insurer gets, and it is a grossly inadequate one at that when compared with the sum to be paid by the insurer. As the Massachusetts court said, the insurer's duty is "to pay a very large sum for which only a small consideration is given." Such contracts are aleatory in character. The premium is the legal and agreed equivalent of the insurer's promise; but no one supposes that it is equivalent to the insurer's promised performance. The law recognizes that a premium of one hundred dollars is not equivalent to a loss of ten thousand dollars. In order to make such a contract valid, inasmuch as the mutual performances are not equivalent in amount, it is necessary that they shall not be equally certain of performance. The small sum makes up in certainty what it lacks in amount, and the large sum makes up in amount

20 No attempt will be made in this article to determine the principles governing the obligee's recovery in quasi-contract for a part performance. 
what it lacks in certainty. But just as the law leaves matters of value and amount to the parties themselves, so also does it leave the matter of the degree of certainty. Assuming that the contract is not illegal because of its wagering element, the parties may determine for themselves the relative degrees of certainty of performance. So $A$ may pay $B$ one hundred dollars in return for B's promise to pay ten thousand dollars on condition of death by railway accident, or in return for B's promise to pay ten thousand dollars on condition of death by either railway accident or by automobile accident. In the second case there is less uncertainty of performance by $\mathrm{B}$, and $\mathrm{A}$ gets more (a more valuable promise) for his money; but the contract is valid in either case.

It follows that if the condition was agreed upon, not as affording merely a mode of proof, but in order to determine the degree of uncertainty of performance by the obligor, it cannot be nullified by the court on the ground of impossibility without robbing the obligor-without making him pay money for which he has received less than the agreed consideration. Thus, in the case just stated above, the condition precedent was death by railway accident. Suppose that this condition is rendered impossible by A's early death from disease, shall the insurer's duty be declared unconditional and shall he be compelled to pay the ten thousand dollars because the condition has become impossible? To state the question is to answer it.

The conclusion may thus be restated: If by making the obligor perform in spite of the nonperformance by the obligee of a condition of the obligation would require performance for a substantially less performance in exchange than was agreed upon by the parties, it should not be done even though the nonperformance was due to impossibility. This would always be the case in aleatory contracts where the uncertainty of the condition was the element that made the promises equivalent; and it would be the case in all contracts, aleatory or not, where the condition is itself a substantial part of the equivalent or consideration to be received by the obligor in return for his performance. ${ }^{21}$

. If, on the other hand, the fact described by the parties as a condition does not form a substantial part of the expected equivalent, the courts are almost certain to nullify it as a condition in case its performance becomes impossible; they are, very likely to nullify it if its perform-

21 In the case of a bilateral contract it is the plaintiff's promise that is the technical "consideration" for the defendant's promise. The history of implied conditions, however, shows that both the parties and the courts regard the performance promised by the plaintiff (rather than his promissory words) as the defendant's essential object of desire. The writer has therefore followed court usage in referring to the plaintiff's performance as the "equivalent or consideration" for the defendant's performance. It may occasionally be difficult to determine whether or not the condition was regarded by the parties as a part of this consideration, and it is very often difficult to determine whether or not it is a "substantial" or "vital" part. The solution of these difficulties is not within the scope of this article. 
ance becomes unreasonably difficult or expensive, and they occasionally nullify it even though its nonperformance was the result of conscious choice by the obligee. This may appear to some to be directly contra to the expressed will of the parties and to be a material limitation of our freedom of contract. But we must remember that freedom of contract always had its limits and that the expressed will of private individtuals never prevailed as against the consciously understood need and desire of the community.

SCHOOL OF LAW,

ARTHUR - I. CoRbIN

YALE UNIVERSITY 